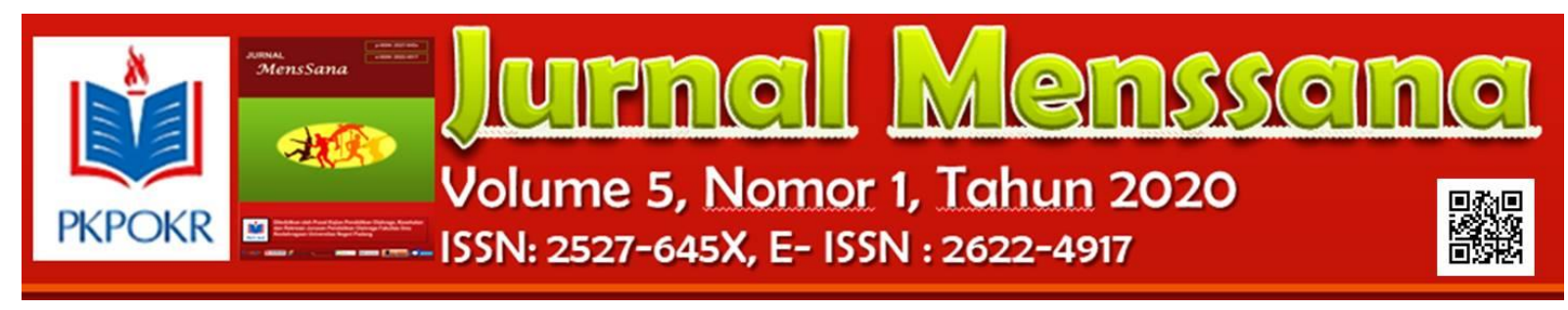

\title{
The Influence Of Drill, Small Game, And Agility Exercise Methods Against Dribbling Capability Of Students At Football Association Junior Football School District XIII Koto Kampar
}

\author{
Syahrastani $^{1}$, Fajri Kamal ${ }^{2}$ \\ ${ }^{1}$ Faculty of Sport Science, University of Padang, Indonesia. \\ ${ }^{2}$ Student of Master Degree Program of Sport Science, University of Padang, Indonesia. \\ E-mail:syahrastani@ yahoo.com ${ }^{1}$, fajrikamal1994@yahoo.com ${ }^{2}$
}

Received: 15 April 2020; Revised: 20 April 2020; Accepted: 30 April 2020

https://doi.org/ 10.24036/jm.v5i1

\begin{abstract}
Football is a popular sport that is loved by many people. In a football game, a player must master various basic football playing techniques and skills. Dribbling is one of the basic techniques for starting an individual game that eventually continues into the team. Based on observations and discussions with Football School coach of Football Association Junior District XIII Koto Kampar, it was revealed that when players do training or matches, players are not consistently doing dribbling quickly and aggressively to pass the opponent. This might occur due to poor training routines and improper learning methods. Among the many training methods that aim to improve (correct) the ability of dribbling, drill training methods and small game methods can be an option. Dribble movements must be combined with ball possession, agility, and speed in running while dribbling. The purpose of this study was to determine the effect of drill, small games, and agility exercise methods on the dribbling ability of the students of Football Association Junior Football School District XIII Koto Kampar. The method used is quasi experiment. This type of research is quantitative with a $2 \times 2$ factorial design. Dribbling capability data obtained were analyzed by analysis of variance (Anava) of two paths and continued with the Tukey test. The results of the study are: students who are trained by the drill method have the ability to dribbling faster than the small games method; there is an interaction of training methods with the agility of dribbling skills; students who have high agility have the ability to dribbling faster if trained with the drill method rather than the small game method; while students who have low agility have the ability to dribbling faster if trained with the small game method rather than the drill method.
\end{abstract}

Keywords: Drill Exercise Methods, Small Game Exercise Methods, Agility, Dribbling

\section{INTRODUCTION}

Football is a popular sport that is loved by many people, from children to parents and is played from remote villages to cities. Football games are sports that require very good stamina, because the duration of play takes $2 \times 45$ minutes, certainly not an easy thing to complete it. Football is a game that uses balls which are played by two teams, each consisting of 11 players. When playing, the player is allowed to use all parts of the body except the hands and arms, only the goalkeeper is allowed to play the ball using his hands in the penalty box. Subardi and Setiawan (2007) stated that to be able to achieve good teamwork requires players who can master all the parts and various basic techniques and skills of football playing.

Football school (SSB) is an informal media for training center in order to increase students' interest and talent for football. In principle, in 


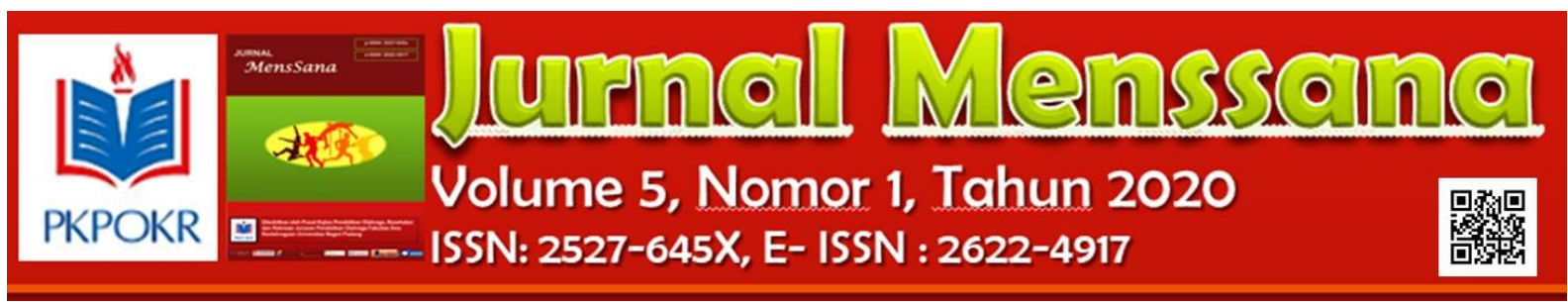

SSB students are trained in the basic skills of playing football and are fostered by their physical quality based on age level, and in accordance with the principles in training. According to Syaifuddin, M.F., Hariyoko., and Wahyudi, U. (2017) a quality football player must have good individual techniques, good mentality, an understanding of adequate play, and supporting physic.

A player must master the basic techniques in playing football. Players must be able to work together with the team in order to score goals. Luxbacher (2011) states that in football there is only one ball that must be shared with 22 players. The success of an attack depends on each player's ability to master the ball. The ability to defeat opponents in dribbles in one-on-one situations (especially in a third of the area of attack), and the ability to deal with opponents who try to seize the ball is critical for individual and team success.

To become a good football player, a player must be able to master various basic techniques in playing football. Dribbling (herding) is one of the basic techniques for starting an individual game that eventually continues into the team. According to Muhajir (2004), dribbling can be interpreted as changing the direction and speed of the ball with quick foot touches. Rizkiyanto., Sugiharto., and Soenyoto, T., (2018) stated that a football player must master the dribbling technique well, because it allows players to make space, control the ball, and pass the opposing players.

Dribbling technique is a skill that must be mastered by every player. Dribble movements must be combined with ball possession, agility, and speed in running while dribbling. If all these elements have been mastered, then the player is included in the player who has perfect dribbling skills. According to Muhajir (2004) agility is the ability of a person to be able to change direction quickly and precisely when moving without losing balance. Gamble (2013) states that agility in team sports not only consists of the ability to change the direction of movement, but also the ability to anticipate the movements of opponents, read and react to certain game situations.

Based on observations and discussions with Football School coach of Football
Association Junior District XIII Koto Kampar, it was revealed that when players do training or matches, players are not consistently doing dribbling quickly and aggressively to pass the opponent. So counter-attacks often fail, and players also easily lose ball control when dribbling. This might occur due to poor practice routines and inappropriate learning methods.

The learning method is an important aspect in the learning process. Whatever method is used by the trainer it is compulsory to keep applying the existing training rules, namely regarding the principles of training and the imposition of training. Among the many training methods that aim to improve (correct) the ability of dribbling, drill training methods and small game methods can be an option.

The drill method is a method in the form of a game that is done repeatedly so that responses become strong, so they have certain skills (Hulfian, 2017). The percentage of students who succeed in dribbling skills always increases if given drill training methods in football games (Aprianova and Hariadi, 2016). Whereas small game is a form of game that does not have standard rules in doing so. In playing students can receive a lot of stimulation, it makes them happy and add a variety of motor skills, social interaction skills, and knowledge (Hartati, S.C.Y., Priambodo, A., dan Kristiyandaru, A. 2012). This study reports on the effect of drill training methods, small games, and agility on the dribbling ability of Football Association Junior Football School XIII Koto Kampar students.

\section{METHOD}

The method used is quasi experiment. This type of research is quantitative with a $2 \times 2$ factorial design. The study population was students of U12 Football Association Junior Football School District XIII Koto Kampar, amounting to 24 people. The sampling technique was total sampling, so that the entire population of 24 people was sampled. Sample grouping is done by the first step to measure the agility of population members, so that a sample of 12 people for the high agility group and 12 people for the low agility group is obtained. After that the sample of 24 people was divided by paired 


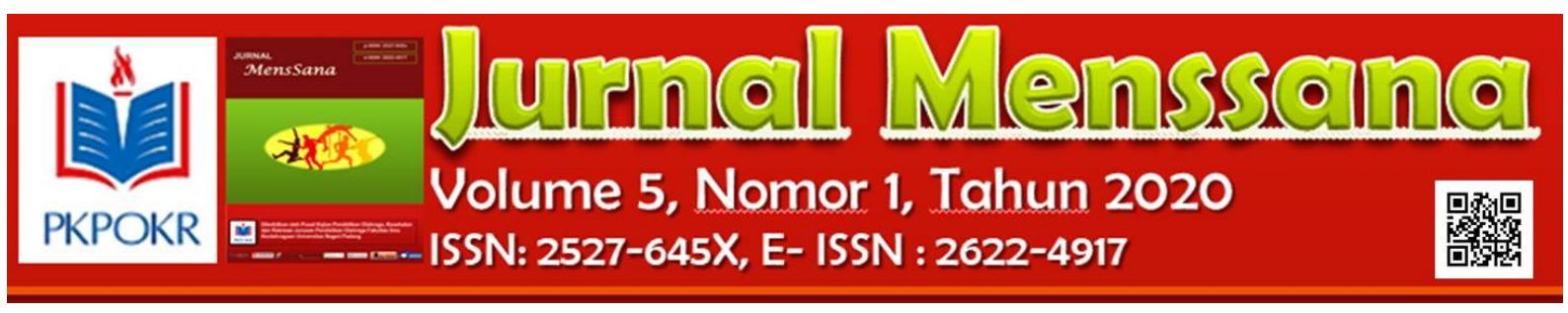

ordinal matching techniques so that it was divided into four groups, which is: two groups to practice in drill methods with high and low agility categories, and two other groups to practice in small game methods with high and low agility categories (Table 1).

Table 1. Research Sample.

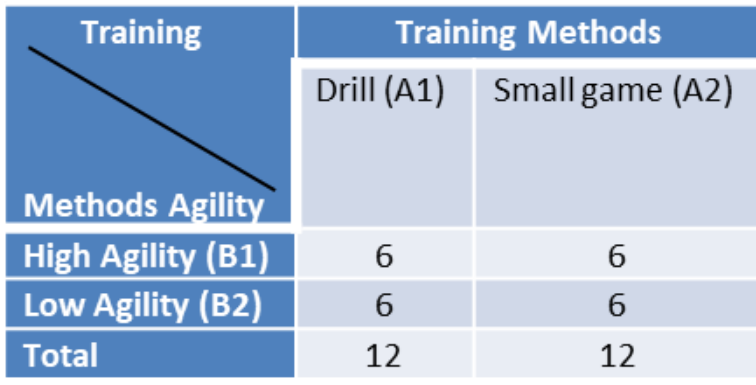

The data of football dribbling ability obtained were analyzed by analysis of variance (ANOVA) of two paths and continued by Tukey test. Before the analysis, the prerequisite test for variance analysis is the normality test using the Lilliefors test, and the homogeneity test using the Bartlett test. From the results of the normality test it can be concluded that all groups of data are drawn from populations that are normally distributed (Table 2).

Table 2. Summary of Normality Test Calculation Results

\begin{tabular}{ccccc}
\hline Groups & $\mathbf{N}$ & $\mathbf{L}_{\mathbf{h}}$ & $\mathbf{L}_{\mathrm{t}}$ & Summary \\
\hline $\mathbf{A}_{1}$ & 12 & 0,1064 & 0,242 & Normal \\
$\mathbf{A}_{2}$ & 12 & 0,1279 & 0,242 & Normal \\
$\mathbf{B}_{1}$ & 12 & 0,1272 & 0,242 & Normal \\
$\mathbf{B}_{2}$ & 12 & 0,1109 & 0,242 & Normal \\
$\mathbf{A}_{1} \mathbf{B}_{1}$ & 6 & 0,1217 & 0,319 & Normal \\
$\mathbf{A}_{1} \mathbf{B}_{2}$ & 6 & 0,1477 & 0,319 & Normal \\
$\mathbf{A}_{2} \mathbf{B}_{1}$ & 6 & 0,1411 & 0,319 & Normal \\
$\mathbf{A}_{2} \mathbf{B}_{2}$ & 6 & 0,1779 & 0,319 & Normal \\
\hline
\end{tabular}

Homogeneity test results concluded the data came from a homogeneous population (Table 3).

Table 3. Summary of Homogeneity Test Calculation Results

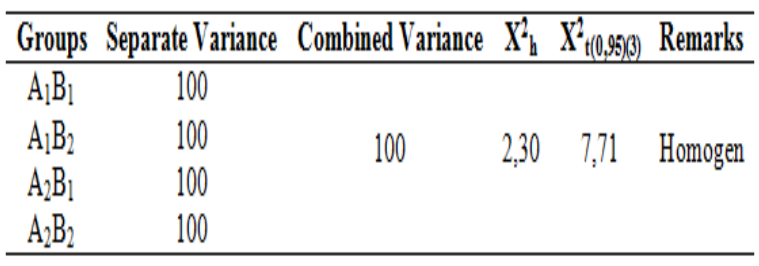

The research hypothesis is:

1. $\mathrm{H}_{0}$ : The dribbling ability of students who are trained by the drill method $\left(A_{1}\right)$ is slower than those who are trained by the small games $\left(\mathrm{A}_{2}\right)$ method.

$\mathrm{H}_{1}$ : The dribbling ability of students who are trained by the drill method $\left(\mathrm{A}_{1}\right)$ is faster than those who are trained by the small games $\left(\mathrm{A}_{2}\right)$ method.

2. $\mathrm{H}_{0}$ : There is no interaction between the training methods with the agility of dribbling skills.

$\mathrm{H}_{1}$ : There is an interaction between the training methods with the agility of dribbling skills.

3. $\mathrm{H}_{0}$ : Students who have high agility have slower dribbling skills if trained with the drill method $\left(A_{1} B_{1}\right)$ than the small game method $\left(A_{2} B_{1}\right)$.

$\mathrm{H}_{1}$ : Students who have high agility have the ability to dribbling faster if trained with the drill method $\left(\mathrm{A}_{1} \mathrm{~B}_{1}\right)$ than the small game method $\left(\mathrm{A}_{2} \mathrm{~B}_{1}\right)$.

4. $\mathrm{H}_{0}$ : Students who have low agility have slower dribbling skills if trained with the drill method $\left(\mathrm{A}_{1} \mathrm{~B}_{2}\right)$ than the small game method $\left(\mathrm{A}_{2} \mathrm{~B}_{2}\right)$.

$\mathrm{H}_{1}$ : Students who have low agility have the ability to dribbling faster if trained with the drill method $\left(\mathrm{A}_{1} \mathrm{~B}_{2}\right)$ than the small game method $\left(\mathrm{A}_{2} \mathrm{~B}_{2}\right)$.

\section{RESULTS AND DISCUSSION \\ Research result}

The hypothesis testing procedure in this study used two-way ANOVA and continued with the Tukey test. The results of the calculations that have been made can be seen in Table 4 .

In Table 4.it is seen for the training method obtained $F_{\text {count }}=126.76>F_{\text {table }}=4.35$. So that the training methods given can affect students' dribbling skills. The interaction between training methods and agility was obtained $F_{\text {count }}=109.75$ 


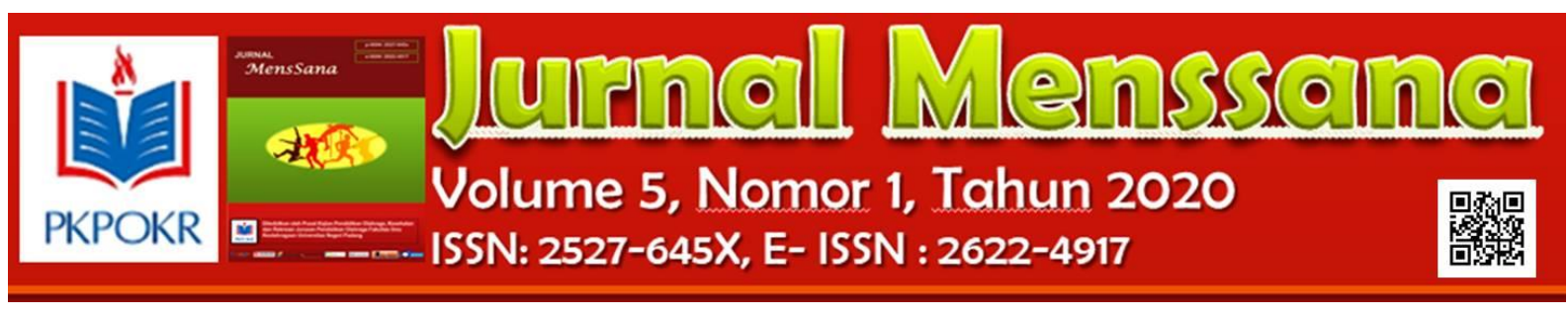

$>\mathrm{F}_{\text {table }}=4.35$. Therefore, the interaction between training methods and agility can affect students' dribbling abilities. The analysis was continued using the Tukey test.

Table 4. Summary of Anova Results Two Data Paths for Dribbling Capabilities.

\begin{tabular}{|c|c|c|c|c|c|}
\hline $\begin{array}{c}\text { Variance } \\
\text { Sources }\end{array}$ & db & JK & KT & $\mathbf{F}_{\text {count }}$ & $\begin{array}{c}\mathbf{F}_{\text {table }}(\boldsymbol{\alpha}= \\
\mathbf{0 , 0 5})\end{array}$ \\
\hline $\begin{array}{l}\text { Between } \\
\text { training methods } \\
\text { (A) }\end{array}$ & 1 & 137,553 & 137,553 & 126,76 & 4,35 \\
\hline $\begin{array}{l}\text { Between agility } \\
\text { (B) }\end{array}$ & 1 & 18,235 & 18,235 & 16,80 & 4,35 \\
\hline $\begin{array}{l}\text { Interaction }(\mathrm{A} x \\
\mathrm{B})\end{array}$ & 1 & 119,094 & 119,094 & 109,75 & 4,35 \\
\hline Within Groups & 20 & 21,703 & 1,085 & - & \\
\hline Total & 23 & 296,585 & & ـ & \\
\hline
\end{tabular}

The summary of Tukey's test results can be seen in Table 5.

\begin{tabular}{|c|c|c|c|c|}
\hline The group being compared & DK & a & $Q\{a=0,05\}$ & Rematss \\
\hline $\mathrm{A}_{1} \mathrm{nnd} \mathrm{A}_{2}$ & 2,2 & 5,86 & 3,08 & Significant \\
\hline $\mathrm{B}_{2}$ and $\mathrm{B}_{2}$ & 2,2 & 109,75 & 3,08 & Significant \\
\hline$A_{1} B_{1}$ and $A_{2} B_{1}$ & 4,36 & 4,64 & 3,96 & Sigificant \\
\hline$A_{1} B_{2}$ and $A_{2} B_{2}$ & 4,36 & 3,73 & 3,96 & NotSiginifent \\
\hline
\end{tabular}

Based on the results of further tests using the Tukey Test it can be stated that:

1. The first research hypothesis $\left(\mathrm{H}_{1}\right)$ which states the dribbling ability of students trained by the drill method $\left(\mathrm{A}_{1}\right)$ is faster than those trained with the small games $\left(\mathrm{A}_{2}\right)$ method is accepted, because $\mathrm{Q}_{\mathrm{c}}=5.86>\mathrm{Q}_{\mathrm{t}}=3.08$.

2. The second research hypothesis $\left(\mathrm{H}_{1}\right)$ which states that there is an interaction between the training method and the agility of dribbling ability is accepted, because $F_{\text {count }}=109.75>$ $\mathrm{F}_{\text {table }}=4.35$. This means that the dribbling ability of students is determined by the interaction between the training methods and the agility of the students.

3. The third research hypothesis $\left(\mathrm{H}_{1}\right)$ which states students who have high agility have the ability to dribbling faster if trained with the drill method $\left(\mathrm{A}_{1} \mathrm{~B}_{1}\right)$ than the small game $\left(\mathrm{A}_{2} \mathrm{~B}_{1}\right)$ method is accepted, because $\mathrm{Q}_{\mathrm{c}}=4.64$ $>\mathrm{Q}_{\mathrm{t}}=3.96$.

4. The fourth research hypothesis (H1) which states students who have low agility have the ability to dribbling faster if trained with the drill method (A1B2) than the small game (A2B2) method is rejected, because Qc $=3.73$ $<\mathrm{Qt}=3.96$.

\section{Discussion}

The results of the first hypothesis testing showed that the overall score of dribbling ability of students who were given the drill method was higher than those given the small game method. From these findings it can be argued that the drill method is more effectively used to improve students' dribbling skills than the small game method. Hulfian (2017) states the drill method is a method in the form of a game that is repeated repeatedly so that the response becomes strong, so that it has certain skills. With this method students will become more active during practice.

The drill method is very beneficial for students in understanding the training material provided. Students become more confident and make them better understand dribbling skills in football games. According to Majid (2013) the drill method is generally used to obtain a agility or skill from what has been learned. Aprianova and Hariadi (2016) reported that the drill method can improve (correct) the basic techniques of dribbling of the football school students in Putra Zodiac, Bojonegoro Regency aged 13-15 years.

In this study there is an interaction between training methods with agility in influencing dribbling abilities. In this case, it means that the training method and agility together have an effect on increasing dribbling ability, or in other words the training method affects the improvement of dribbling ability which depends on the agility of students. According to Muhajir (2004) agility is the ability of a person to be able to change direction quickly and precisely when moving without losing balance.

Agility as an individual's ability to move the position and direction of motion quickly and precisely in the faced and desired situation involving physical elements that support the process. In football games, agility is very necessary when changing the direction of motion quickly. When running a football player who has to pass an opponent requires agility when dribbling. Agility is the ability to do a movement that is short or fast in the shortest possible time. So high agility is very important to be possesed by Football Association Junior Football School 


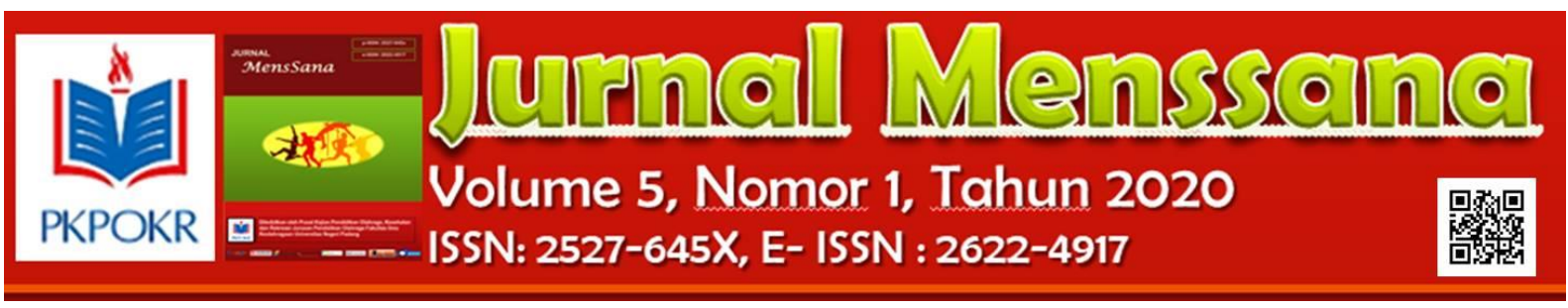

players of District XIII Koto Kampar in order to achieve training programs that have been made to improve dribbling skills.

The results of the third hypothesis testing indicate that overall, students who have high agility produce a quick dribbling ability if given training with the drill method rather than the small game method. The drill method is carried out by first presenting training material in a systematic, planned, simultaneous, and overall manner with an improvement process in an exercise that results in a relationship between stimulus and response. Drill exercises are very useful in motor teaching. Sagala (2009) suggests the drill method is a training method which is a good way of teaching to instill certain habits. Besides that, it is also a means to acquire agility, accuracy, opportunity and skills.

The fourth hypothesis testing results show that overall, students who have low agility produce high dribbling skills if given training with the small game method rather than the drill method. This is a different matter when seen in students who have high agility, better dribbling ability if trained with the drill method.

For students who have low agility, training using the small game method is a very popular activity. The small game method directly leads to the game process, so that moving without any restrictions makes participants more free and passionate to reach the level of movement automation in the game process. Therefore the small game method can help students practice their agility. The results of Hartati's research (2012) reported that the application of the small game method can influence the collaboration of students in learning physical education, health and sports (PJOK). According to Van Boxtel (2000) cooperative attitude is an activity carried out in groups and becomes a form of social interaction that is associative and fun to achieve the same goal.

\section{CONCLUSION}

Based on the research that has been done, the following conclusions can be drawn:

1. Students trained in drill methods have dribbling skills faster than those trained in small games
2. There is an interaction between the training methods with the agility of dribbling skills.

3. Students who have high agility have the ability to dribbling faster if trained with the drill method rather than the small game method.

4. Students who have low agility have the ability to dribbling faster if trained with the small game method rather than the drill method.

\section{CITATIONS AND REFERENCES}

Aprianova, F dan Hariadi, I. (2016). Metode Drill Untuk Meningkatkan Teknik Dasar Menggiring Bola (Dribbling) Dalam Permainan Sepakbola Pada Siswa Sekolah Sepakbola Putra Zodiac Kabupaten Bojonegoro usia 13-15 tahun. Jurnal Kepelatihan Olahraga, Vol 1 No 1 Oktober 2016

Gamble, P. (2013). Strength and Conditioning for Team Sports: Sport-Specific Physical Preparation for High Performance. 2nd ed., London and New York, Routledge: Taylor and Francis.

Hartati, S.C.Y., Priambodo, A., dan Kristiyandaru, A. (2012). "Permainan Kecil (Cara Efektif Mengembangkan Fisik, Motorik Keterampilan Sosial dan Emosional)". Malang. Wineka Media.

Hulfian, L. (2017). Aplikasi Variasi Latihan Drill Game Dalam Peningkatan Daya Tahan dan Keterampilan Menggiring Bola. Jurnal Dosen Prodi Pendidikan Olahraga FPOK IKIP Mataram. Volume 4, No 1, Hal 1-5.

Luxbacher, J.A. (2011). Sepak Bola. Jakarta: Rajagrafindo Persada.

Majid, Abdul. (2013). Strategi Pembelajaran. Bandung: Remaja Rosdakarya.

Muhajir. (2004). Pendidikan Jasmani Teori dan Praktek. Jakarta: PT Gelora Aksara Pratama. 


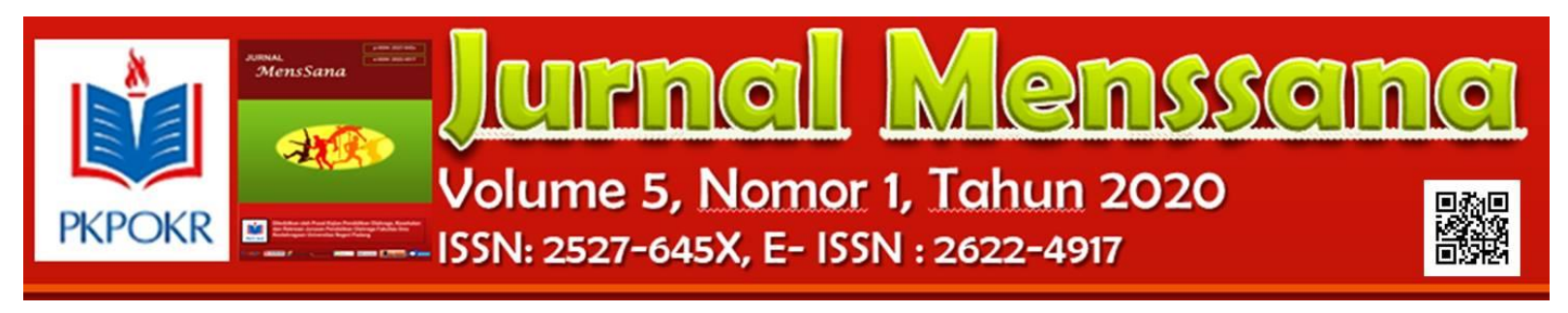

Rizkiyanto., Sugiharto., and Soenyoto, T. (2018).

The Effect of Exercise and Agility on Speed Dribbling Football Extracurricular MTs Al-Uswah Semarang. JPES 7 (1) (2018) : $95-99$

Sagala, Syaiful. (2009). Konsep dan Makna Pembelajaran Untuk Membantu Problematika Belajar dan Mengajar. Bandung: Alfabeta.

Subardi, W dan Setiawan, A. (2007). Olahraga Kegemaranku Sepakbola. Klaten: Intan Pariwara.

Syaifuddin, M.F., Hariyoko., dan Wahyudi, U. (2017). Pengaruh Metode Drill dan Metode Bermain Terhadap Hasil Belajar Passing Sepakbola pada Peserta Ekstrakurikuler Sepakbola Usia 16-17 tahun. Gelanggang Pendidikan Jasmani Indonesia 1 (2) (2017)

Van Boxtel, C. (2000). Collaborative Concept Learning. ICO. Copyright 2000, C.A.M. Van Boxtel, Gemert. 